\title{
MARKETING ENDORSEMENT STRATEGY IN BATIK KAMPUS: ISLAMIC BUSINESS ETHICS PERSPECTIVE
}

\author{
Marita Hadikha1, Ali Muhtarom², Hendri Hermawan Adinugraha 3 \\ 1,2,3 State Islamic Institute of Pekalongan \\ Corresponding Email: hendri.hermawan@iainpekalongan.ac.id
}

Received: 22-03-2021/Accepted: 30-06-2021/ Doi: https://doi.org/10.32923/sci.v6i1.1691

\begin{abstract}
This research aims to describe the problem of endorsement as a marketing strategy for Batik Kampus Online Shop Buaran Pekalongan from the perspective of Islamic business ethics. The approach used in this research is phenomenology. The research location is in Buaran Pekalongan precisely on Jl. Pelita II, No. 54, Jenggot Gang 4. Sources and data collection techniques in this study using semi-structured interviews, participatory observation, and documentation. Internal validity is done using triangulation, emic and member checking. Data analysis using reduction, display and drawing conclusions. The results of this study concluded that the endorsement marketing strategy carried out by Batik Kampus via Instagram and telegram contained two types of endosers, namely testimonials and celebrity appeal. Endorsement as a Kampus Batik marketing strategy in terms of Islamic Business Ethics as a whole on social media. The products that Batik Kampus promote are not exaggerating and in accordance with Islamic Sharia principles. Products that are traded include products that are polite and cover the body. The use of endorsement as a marketing strategy by Batik Kampus has had a significant positive impact as evidencing by the increased sales turnover and the increase in admins who help him in online business in the market place and proven by the assets owned by Moh. Abdul Ghoni. Kampus Batik services are very fast, friendly and accept dropshipping or packaging which can make it easier for buyers to buy and resell Batik Kampus products to consumers directly.
\end{abstract}

Keywords: Marketing, Endorsement Strategy, Batik Kampus, and Islamic Business Ethics.

\begin{abstract}
ABSTRAK
Penelitian ini berupaya untuk mendeskripsikan permasalahan tentang endorsement sebagai strategi pemasaran Batik Kampus dalam perspektif etika bisnis Islam. Penelitian ini adalah kualitatif. Pendekatan yang digunakan dalam penelitian ini adalah fenomenologi. Lokasi Penelitian berada di Buaran Pekalongan tepatnya di Jl. Pelita II, No. 54, Jenggot Gang 4. Sumber dan teknik pengumpulan data dalam penelitian ini menggunakan wawancara semi-terstruktur, observasi partisipatif, dan dokumentasi. Validitas internal dilakukan menggunakan triangulasi, emic dan member checking. Analisis data menggunakan reduksi, display dan penarikan simpulan. Hasil penelitian ini menyimpulkan bahwa strategi pemasaran dengan endorsement yang dilakukan oleh Batik Kampus melalui instagram dan telegram terdapat dua jenis endoser yang berlaku yaitu testimonial dan daya tarik selebriti. Endorsement sebagai strategi pemasaran batik Kampus ditinjau dari Etika Bisnis Islam secara keseluruhan di media sosial. Produk yang di promosikan Batik Kampus tidak melebih-lebihkan dan sesuai dengan prinsip-prinsip Syariah Islam. Produk yang diperdagangkan termasuk produk yang sopan dan menutup badan. Penggunaan endorsement sebagai strategi pemasaran oleh Batik Kampus menimbulkan dampak positif yang signifikan dengan dibuktikan omset penjualan yang meningkat dan bertambahnya admin yang membantunya dalam bisnis online di market place serta dibuktikan dengan asset yang dimiliki oleh Moh. Abdul Ghoni. Pelayanan Batik Kampus sangat cepat, ramah dan menerima dropship atau packanging yang dapat memudahkan pembeli untuk membeli dan menjual kembali produk-produk Batik Kampus kepada konsumen secara langsung.
\end{abstract}

Kata Kunci: Pemasaran, strategi endorsement, Batik Kampus, dan etika bisnis Islam. 


\section{Introduction}

Online business is a business marketing activity where products are offered through the internet, meaning that sellers and buyers of products do not have to make face-to-face transactions (Anggraini et al., 2020). Businesses that are mediated by the internet or electronic media have long been used and are known as e-commerce, but at that time their development was not widely known by businessmen or consumers (Escursell et al., 2021). Only businessmen who have large capital and who know their intelligence in digital technology can do business online first (Tran, 2021). The emergence of ecommerce makes it easier for businesses to carry out marketing strategies and makes it easier for consumers to transact by considering transportation costs, saving time and being able to choose various prices and kinds of products from all stores around the world. Marketplace is part of e-commerce. The marketplace appears to offer various kinds of convenience for business transactions. In Indonesia, the emergence of marketplaces such as Tokopedia in 2009 then Bukalapak in 2010 as well as Lippo group, zalora, olx, blibli, Jd.id and others. With the media marketplace, the sales volume has increased dramatically. To deal with increasingly sophisticated business and information developments, business people are required to be able to follow the development of the digital era. Especially with the Covid-19 outbreak in early 2020 in Indonesia and the announcement of social distancing, online shops are the right media for doing business (Mofijur et al., 2021).

The success of an online shop company is very much determined by the marketing efforts and the accuracy of the products produced in providing decisions from the specified target consumers (Hartati, 2019). Every online shop businessman has the goal of directing his business activities to produce products that provide customer satisfaction, so this makes the seller carry out an advertising strategy with an endorsement strategy. Endorsement strategy is a marketing communication strategy using well-known figures such as artists, fashion bloggers, fashion stylists and others as a means of supporting and supporting people's interest in buying products (Rosadi et al., 2019).

Even now, there are many models from ordinary backgrounds who become advertising models by showing the attractive side and details of the advertised product. Online shop businessmen ask for endorsement models for photos using advertised products and share them on social media that they have such as Instagram, Twitter, YouTube and others. In addition, endorse also use audio visuals such as recording product details and describing them in very interesting language (Wenny Desty Febrian \& Fitri, 2020). The fee that is charged from the famous artist or blogger is quite expensive, up to IDR $3,000,000$ for one-time product. As a beginner businessman who plays an online shop, he prefers the usual model for photos and advertises his products to be posted in catalogs such as telegram or Instagram and the marketplace that the businessman uses.

Marketing strategies using endorsements have been carried out by many business people, both in the business of clothing products, food, beverages, furniture, cosmetic tools, cosmetics, household appliances, furniture, building materials and many more, almost all product advertisements use endorsements (Zhang \& Hung, 2020; Yu \& Hu, 2020). Because with this social media, the public can quickly see and follow what is currently viral about the development of any issue and especially in the business sector. Like Instagram, Instagram has long been used by businesses to promote and sell products or services to other Instagram users (Ghoshal, 2019). Instagram itself is an application used to take photos, manage photos, photo editing, and share with everyone (Herman et al., 2018). In addition, Instagram can also record videos, which then endorsers or celebrities can record and describe products by including the Instagram account of the businessman who uses the service of the endorse (Iconsquare \& HubSpot, 2016). Instagram users whose followers are many, especially artists, can get very high pay, so in the end people compete to style like artists who want to become endorsers or celebrities to get money (Alkhowaiter, 2016; K \& Kozhukkal, 2020).

Apart from Instagram which can be accessed by various levels of society, namely the Yutub, Facebook, Twitter, Telegram application and recently using the TikTok application. By promoting these goods or services it can be seen by all people, both at home and abroad (Ahmed \& Cookson, 2016; Hashim, 2017; Islam, 2019). Sometimes endorsers or celebrities in promoting a product are based on perception alone, not according to reality. Even the products being promoted are not used in real terms or the validity is not yet known. Selebgrams are also excessive in promoting their products both verbally and in writing that the endorse products are of good quality and quality even though they themselves do not know exactly how the product is, so in this case there is an impression of lies and fraud. This is 
certainly very disappointing to customers and is definitely against business ethics in Islam.

Some research related to this research topic such as the concept of endorsement in the Islamic perspective is siddiq (true and honest), amanah (trustworthy), fathonah (intelligent) and tabligh (communicative). The characteristics of the endorsement in Islam are divine, ethical, realistic and humanistic (Rosadi et al., 2019). Ambaryati Hartati's (2019) thesis reveals that the marketing strategy of Hayu Olshop uses two types of endorsers, namely, the type of testimonial is a character who comes from ordinary people who are considered neutral and the assessment type is the use of a character who is unique in a certain field. Business people are not selective in recruiting celebrities as well as endorsers who accept solely because of their pay. Selebgram seems to exaggerate promotions and in the end there is an element of lies so that consumers feel disadvantaged (Nasih et al., 2020). This is prohibited in Islam because there are elements of lies and injustice and can lead to disputes. Selebgram has not used Islamic business ethics which should apply.

Furthermore, the reason for choosing Pekalongan City as the research location is because Pekalongan is known as the City of Batik which has great potential in batik activities and has developed so rapidly, both on a small and large scale (Susanti, 2019; Faradies, 2020). The results of Pekalongan batik production are also one of the pillars of the economy of Pekalongan City and district. The distinctive patterns and colors of the Pekalongan Batik products have made the Pekalongan Batik handicraft more known. The batik industry has been able to export to various countries (Phelps \& Wijaya, 2020). This industry provides a major contribution to the progress of the economy in Pekalongan with the majority of the home industry. Recently online business has grown rapidly, since the implementation of social distancing and PSBB due to the Covid-19 outbreak which resulted in many markets in various areas as well as shopping centers and tourist centers closing, a trader must carry out his strategy to maintain his business and income, one of which must be able doing business online and of course to introduce its products using advertising services through endorsements.

Buaran is one of the districts with the largest number of Batik craftsmen compared to other districts in Pekalongan. One of the online shops, namely BATIK KAMPUS, is located on Jl. Pelita II no 54 Jenggot is in the vicinity of Buaran Pekalongan sub-district. Batik Kampus has been using the online shop business for years, besides the unique shop name and the owner is a young entrepreneur who is still undergoing his studies at STAIN Pekalongan. Batik Kampus uses endorsee services from well-known artists such as Amanda Manopo, Natasha Willona, Arya Saloka, Laudia Cintya Bella, Gishel Anastasya, and uses local models to promote their products.

Based on the research phenomenon and the above background, the researcher is interested in describing endorsement as a marketing strategy in terms of Islamic business ethics, where the research location is in Batik Kampus Online Shop Buaran Pekalongan. Therefore, this study seeks to answer the problem of endorsement as a marketing strategy for Batik Kampus Online Shop Buaran Pekalongan from the perspective of Islamic business ethics.

\section{Theoretical Framework}

Marketing is an activity, a set of institutions and the process of creating, communicating, delivering and exchanging offers that are of value to customers, clients, partners and the general public (Appel et al., 2020). Meanwhile, according to Kotler (2017), marketing is a social and managerial process carried out by a person or group to get what they want and want through offering and exchanging valued products with others. Based on the above understanding, it can be concluded that the process of introducing a product in question or offered to consumers is through marketing. Thus from marketing there are several strategies in which a product can be valued and enjoyed by customers according to marketing goals and targets. One of them is the marketing mix which includes product, price, promotion, and place (Purohit et al., 2021). The connection with this research is promotion.

Promotion is the activity of a seller (personal/company) company (seller) to invite and encourage consumers to be interested in and buy the goods offered or advertised (Keller et al., 2019). There are 4 promotional means, namely a) Advertising (Advertising) such as installing billboards on the road, strategic places or locations, distributing brochures and others, b) Sales promotion (sales promotion), this promotion is carried out to attract customers to immediately buy each product or services offered so that customers are interested in buying, it must be made as attractive as possible, c) Publicity through activities such as exhibitions, social services, and other activities, d) Personal selling, namely sales of 
products carried out directly by the salesman and/or salesgirl in a door to door way (Good et al., 2021). Based on the understanding and marketing strategy above, endorsement activities include marketing strategies that use promotional tools, namely advertisements that are made as attractive as possible either with photos or videos so that consumers can understand and believe that everything being promoted has been proven of quality by the artist endorsement (Hakimi et al., 2011). Endorsement itself has a meaning, namely communication activities or introducing a product brand, where the celebrity acts as a spokesperson and supports the brand with all the attributes of popularity, personality, and social status of the celebrity. Endorsers or celebrity endorsers are people who value a product or convey a message in an advertisement with the aim of attracting consumer interest (Adinugraha et al., 2019).

With the advancement of technology, endorsement activities have a very influence on followers and society. Companies use influencers (artists, celebrities, YouTubers, bloggers, etc.) to improve the company's products or services. This is what is known as influencer marketing (Campbell \& Farrell, 2020; Chopra et al., 2021). So that from the endorsement it becomes a separate business area for artists and endorsers who are not artists. This causes endorsement activities to become increasingly uncontrollable, that in promoting products, there are several ethics that need to be considered so as not to contain fraud, coercion or other forms of loss that will be felt by consumers (Waqas et al., 2020). In this case, the businessman also needs to select an endorsers so that his business can be trusted by consumers.

Islamic Business Ethics is the application of morals or morals in business activities in accordance with Islamic law (G. N. O. Widana et al., 2014; G. O. Widana et al., 2015; Handayani, 2019). Islamic business ethics can also be implemented as a sign or rule that is used as a limitation for Muslim business actors to have so that all related parties can fulfill their rights in accordance with Islamic principles derived from the Al-Qur'an and the Prophet's Sunnah in doing business (Ramdania, 2021; Buldan et al., 2021).

\section{Method}

This research is field research because primary data is extracted and obtained directly from respondents in the field (Crump, 2020). The meaning of the field in this case is related to endorsement as a marketing strategy for online shop batik traders in Pekalongan. In addition, this study also intends to prove whether online stores consider Islamic business ethics in promoting their products or not, seeing that many frauds occur as a result of purchasing goods or services via the internet (online). The approach used in this research is phenomenology (Aspers, 2009). The phenomenological approach is intended to obtain new concepts and new strategies in marketing at online stores and at the same time remind the importance of paying attention to business ethics in Islam to create customer loyalty, customer satisfaction and sales volume, so that no more consumers are harmed and have an effect deterrent to online shopping.

The research location is in Buaran Pekalongan precisely on Jl. Pelita II no 54 Jenggot Gang 4 is an online shop called Batik Kampus. The location was chosen because Batik Kampus dared to endorsee famous program and soap opera artists. Batik Kampus is one of the online shop players who for years before the pandemic period until now and the turnover that has been obtained has been billions of rupiah. Sources and data collection techniques in this study through interviews, observation, and documentation. The type of interview conducted was semi-structured, allowing the researcher to ask new questions that emerged in the field. Observations were made by participatory observation.

The validity and credibility of the data is carried out through internal and external validity. Internal validity is done by triangulation, emic and member checking. Meanwhile, external validity or extrapolation is comparing the findings of the researcher (both preliminary and final findings) with the results of other previous studies. Data analysis was processed through three stages, namely reduction, display and drawing conclusions. And the data were analyzed using deductive thinking method.

\section{Results And Discussion}

\section{Profile and History of Batik Kampus}

Batik Kampus is the name of a batik shop that was pioneered by a student who is still carrying out 
his studies at STAIN Pekalongan class of 2014. The student's name is Moh. Abdul Ghoni. He was born in Pekalongan on May 12, 1989. His parents are originally from Pekalongan who reside on Jl. Pelita III no 54 Jenggot Gang 04 Pekalongan. Moh. Abdul Ghoni is a Muslim. Moh Abdul Ghoni was originally already involved in the business world in the field of Batik trading, especially Pekalongan batik products in 2013. He goes to Klewer market in Solo every Monday and Thursday. He offers his merchandise in personal selling. And in 2014 he became a student of the Arabic language education study program at STAIN Pekalongan. He goes to college and arranges his business schedule to Solo once a week.

In 2015, he met a new customer at the Klewer Solo market who was shopping for batik, especially shirts and hem for 5 scores. From there he chats with his customers. He asked his customer, "How come you are just starting out in the batik business, have you dared to take 5 scores, sis? Usually, my new customers only dare to take 1-2 scores, which shop do you sell at? The buyer answered, "I don't have a shop, I only sell at home via online (using the internet)" (interview result with Moh Abdul Ghoni).

That's where Moh Abdul Ghoni learned online from his customers, who at that time only used BBM (Black Berry Massage) and Facebook as the media. Moh. Abdul Ghoni started stocking a variety of his batik clothes at a shop close to the STAIN Pekalongan campus so that they could be controlled after or when there was an empty lecture hour. He is assisted by one employee or admin. From there came the name "Batik Kampus" which is located at the junction of the Walisongo Mosque near the STAIN Pekalongan campus. Batik Kampus was established on September 7, 2015. At that time, a STAIN student called Ghoni was still studying and pursuing his trade by leaving for Klewer Solo market. Ghoni started an online business by taking photos of products to advertise or promote to buyers or resellers (merchants) who both use BBM and Facebook. At that time he asked his friend to use his product to be photographed in front of his house. From the media, the merchandise can be seen by BBM (Black Berry Massage) contacts or Facebook friends.

Over time, more and more people understand online business. Some of the online business people (resellers) are still undergoing their studies and some work part time to fill their daily activities. Batik Kampus is increasingly developing after the Banjarsari market in Pekalongan city caught fire on Saturday, February 24, 2018, where some batik traders or the Pekalongan batik shopping center are in the market.

The burning of the Banjarsari market made consumers or traders who used to shop (kulak) in the market lose track of their tracks. There were also batik traders in Banjarsari who moved to trade at home, however, the distance to their houses was further away and less strategic. From there the Batik Kampus online shop famous for the characteristic backdrop of the Batik Kampus photo model, namely the walls of his house. Batik Kampus opens a branch of its business at home and then focuses its merchandise at home, which can still be said to be strategic, namely on Jl. Beard Lamp. From the Batik Kampus (Jenggot) environment, many batik producers have long been known. Finally, many batik businessmen in the Jenggot area participate in Batik Kampus by doing online business.

\section{Endorsement as a Marketing Strategy of Batik Kampus}

In order to face industrial competition in this digital era, a special strategy is needed so that it can anticipate the impact of an event and be able to act proactively/innovatively to maintain and improve competitiveness. One of the actions that can be taken is how to determine an effective marketing strategy to win the competition. An effective marketing strategy means when the level of sales is stable or will increase from year to year according to the quantity/qualitative of products that are able to be produced by the company. In this case the management must make a strategy that is able to take advantage of various opportunities that exist and try to reduce the impact of existing threats into opportunities (Zunaidi, 2015).

Along with the development of internet technology, a new understanding of the marketing mindset has emerged in the form of modern marketing concepts that involve advances in digital technology and the internet. Or better known now, namely Indonesian e-commerce has actually been around since 1996 but has only grown very rapidly in the past few years along with the development of the internet. Sales systems like this can reach the whole world at the same time and can be done 24 hours without stopping. Companies can expand their activities and consumers more easily, as well as transaction processes that have been conventional so far have become more modern with online transactions. In the past, business activities were only centered on conventional business, but since the 
internet, conventional business activities have developed into online transactions. This proves that the internet provides changes to the business world, it is undeniable that the existence of this online business provides promising benefits for business people (Barger \& Labrecque, 2013).

Therefore, the internet is an inseparable part of people's lives, so many companies and businesses use internet services for both personal and business activities. Mass media is also one of the components in business communication, where the mass media serves as a channel that makes a liaison between producers and consumers. Business communication practices that occur in the mass media always involve parties outside the producers, which are better known as endorsements. Endorsement is a social media promotion that is quite effective. Besides being easy, fast, and cheap, promotions through endorsements are also directed at potential buyers. In the modern business world, endorsement is an activity where business owners endorse or ask celebrities/artists to provide testimony and promote products through their social media such as Instagram, Facebook, Twitter and so on and the business owner will provide the product, plus adding mention the online store account of the business owner. In other words, endorse is a symbol which is also referred to as a direct source of demonstrating products or services in promotional activities. The purpose of these activities is to support the effectiveness of delivering the message of the product or service (Belch et al., 2020).

At this time social media is one of the effective business promotion tools because it can be accessed by anyone. Social media has become an indispensable part of marketers or business people and one of the best ways to reach customers widely. Business cannot be separated from marketing activities. This is because marketing is an activity of planning, implementing, and monitoring programs designed to generate transactions in the target market, to meet the needs of individuals or groups based on the principle of mutual benefit through the use of products, prices, promotions and distribution.

The number of social media that exists today can be used as a place of business which is commonly referred to as an online business. Online business is a business activity, both services and products offered through internet media, from negotiations to transaction activities without having to face with customers. Online shop businessmen have a goal, namely that each online shop directs its business activities to produce products that can provide consumer satisfaction, so that in the long term the online shop gets the expected benefits through the products it produces. The success of an online shop company is largely determined by the success of marketing efforts and the accuracy of the products produced in providing decisions from the specified target consumers.

One of the marketing strategies that is often done is by advertising their products on Instagram by requiring the services of other people called Instagram celebrities who have a large number of followers or followers on their Instagram accounts or commonly referred to as endorsements. The Batik Kampus is no exception, one of the strategies used in marketing its products is using the services of an Instagram artist or celebrity, which is commonly referred to as endorsement. Now the name Batik Kampus is familiar to online businessmen, especially in the district and city of Pekalongan. Moh. Abdul Ghoni markets most of his batik in online shops, about $75 \%$ and the rest is sold outside the city. However, from a financial perspective, Batik Kampus is still financially mixed between online and offline businesses. Batik Kampus is now growing and already has thousands of resellers all over Java.

Batik Kampus sells various kinds of finished clothes such as shirts, hem, dresses, family batik uniforms, couple dresses, homey dresses, One set tiedie and couple kebaya, some of which are printed batik (screen printing). The reason he is focused on batik printing because the process does not take much time and is economical (Mukimin et al., 2017), meaning that prices can still be competitive among the lower middle class. Apart from the batik that is traded the result of his own production, he too selling his friend's products which can help when there are large orders (large parties). This study supports several other research results, such as research from Dyah Utami \& Agus Triyono (2011) and Arwani (2019).

Batik Kampus has started to use local models as endorse at a cost of Rp. 15,000/product photo. Batik Kampus does not use the services of a photographer, she uses her personal camera and takes photos in front of the house she lives in (her parents' house). The marketing strategy used by Batik Kampus is endorsement services that use the characteristics of the walls of the house. Now the photos are published through media market places such as Shopee, Tokopedia, Instagram, Telegram and WhatsApp. He no longer uses BBM or Facebook because these media are no longer considered strategic to market. Consumers can access various kinds of Batik Kampus products through Shopee, Lazada, Tokopedia, Instagram, Telegram and WhatsApp. Product descriptions can be seen from photos that have 
been edited or from the media market place. Now Batik Kampus has reached a lot of national and international business markets. The turnover obtained is already tens of millions in a month. The findings of this study have similarities with several other research results, such as research from Johan Grafström (2018), Venkata Subbiah \& Sathish (2020), Venkata Subbiah \& Sathish (2020), and Schimmelpfennig \& Hunt (2020).

In 2020, when the Covid-19 pandemic entered Indonesia, the development of the Batik Kampus online shop did not experience a significant decline. Sales turnover is still fairly stable. When the government announced the new normal, the development of the online shop Batik Kampus has increased again because during the Covid-19 pandemic, the online business world has indeed become the most strategic step for business marketing and preventing the Covid-19 spread chain, which is transmitted through direct physical contact. Therefore, Ghoni tries to add more marketing strategies using the services of Celebrity Endorsers which already has millions of followers on his account, the goal is to market Batik Kampus products with a wider reach. Artists who have been endorse are Laudya Cintya Bella, Dinda Hauw, Ghisel Anastasya, Natasya Willona, Amanda Manopo, and Arya Saloka. Since using the services of the program, Batik Kampus sales turnover has increased to billions of rupiah. Based on the research results, the findings of this study have also been described by several other researchers, such as Fink et al., (2020), Chakraborty et al., (2020), Haikal et al., (2020), and Zhang \& Hung (2020).

\section{Endorsement Analysis: Marketing Strategy of Batik Kampus in Islamic Business Ethics}

A well-managed Batik business is always in touch with the needs of its consumers, and this type of good relationship with consumers will develop consumer trust and confidence, both of which depend on a strong ethical basis if the company is unethical, good relations with consumers will be damaged and even difficult to repair.

Business ethics in Islam functions as a regulator and supervisor because philosophically Islamic ethics is based on religious reasoning, to assess the foundation in life practice. So that ethics can be applied in business activities in the field of marketing. Therefore, many companies apply ethics that are in accordance with the conditions of the community, one of which is by applying Islamic business ethics in marketing the Batik business (Herlina \& Hakiki, 2020).

In business, of course there is a transaction, the law of origin of the transaction is the pleasure of both parties to the contract and the validity of the contract. The meaning of pleasure is that pleasure in transactions is a principle.

In the sale and purchase transaction, a contract is applied, namely the contract of ijab (statement of making a bond) and qabul (statement of acceptance of a bond) in accordance with the will of the Sharia which affects the object of the engagement. So the contract is an agreement of consent and acceptance that is justified by sharia which determines the willingness of both parties. Akad is an agreement between consent and Kabul in a way that is justified by sharia, which stipulates the existence of legal consequences on the object (Herlina \& Hakiki, 2020).

As a Muslim, in all his activities, he must be based on the basic principles of Islam, namely the AlQur'an and Hadith (Adinugraha, 2018). Ghoni is a Muslim who is known by his community as a good and religious person. His father is a mosque priest who is in front of his house. Ghoni sells its products, which mostly cover the the body, such as the robe, shirt, hem, outer, bluse, dress, tunic and others.

In addition to these products, he also sells batik kebaya clothes, which he markets to see the right moments such as Kartini days or days in the season of many bridal celebrations (Javanese custom), because they can be worn with invitations or batik uniforms. She also sells colors and dresses that follow the moments of Eid or Christmas. The clothes that are sold are still modest clothes. The selection of endorsers Natasha Willona and Ghisel Anastasya for the Christmas moment and Laudya Cintya Bella and Dinda Hauw (hijab artists) to pursue the Eid moment, while Amanda Manopo and Arya Saloka were chosen based on soap opera artists who are currently booming or viral. He thinks that artists who are viral are used for endorse because they are widely seen and are still being discussed by all people. So, this strategy can boost sales of Batik Kampus.

Based on the results of the study, endorserment acts as a guide for consumers in determining their purchasing decisions. However, what kind of endorserment role can directly affect buying interest is a big question, because before a purchase decision is taken, consumers make an assessment of the product so that consumers have perceived quality of the product. Perception of quality will form perception of 
value which is the overall assessment of consumers towards a product and perceived value will be the main factor influencing buying interest. Also based on the research analysis, the endorsement carried out by Batik Kampus is in accordance with Islamic Business Ethics. The findings of this study have also been disclosed in several studies, namely Ismaeel \& Blaim (2012), Sampurno (2016), Rosadi et al., (2019), and Putritama (2018).

It is proven by looking at the testimonials on the Instagram, Telegram, shopee, lazada and WhatsApp Batik Kampus account accounts. The value rating given by consumers to the Batik Kampus online shop is also good and good. This means that Batik Kampus serves purchases well and responds quickly, prioritizes customer satisfaction, is honest and trustworthy. In this case the element of fraud is minimal. Ghoni When asked what if there are consumers who are dissatisfied or complain that their merchandise does not match the price or quality, he answered: "Online trading is very close to the risk of fraud, miss, sometimes doesn't live up (does not match) to his expectations. Yes, it is common. If I have a customer like that, I think he is too hopeful with his own ego, he wants cheap goods with the hope of good quality and material. It is impossible. We also sell according to production prices and profits that I think are applicable in the market (not too high). So far, I do not sell fraudulently, if the price is cheap, so the quality is appropriate, whether he comes directly to the house or online, the goods are the same. If there is a defect in the item, I will accept it in exchange for coming directly to the house or having a package sent, but the shipping cost is borne by the buyer".

Based on the results of the interview, the researcher concluded that Batik Kampus has never cheated or exaggerated fraudulent advertisements (promotions). He also never standardizes endorsers in order to promote products by exaggerating their quality, because some of the products are endorse with photos and if there is a video recorded by the endorsers, the goods are in accordance with the quality of the material and the price. Products endorse to artists are different from ordinary products on the market. The products that he endorse to artists are products that have high artistic value, better quality, neat stitches, and are more expensive. Based on the research results, the findings of this study have also been described by several other researchers, such as Hapsari (2016), Devi S \& Susantiningrum (2017), Haerisma (2018), Rasyidi \& Bariyah (2020), and Arfianti \& Reswanda (2020). Finally, based on the research findings above, Batik Kampus runs an endorsement as a marketing strategy in accordance with Islamic Business Ethics. The results of this study support several other research findings, such as research from Azizah (2020) and Tafesse \& Wood (2021).

Now Batik Kampus has about 10 Admins. In November 2020, Batik Kampus moved her batik stock to her private home which she founded through her hard work through an online business. The house he now lives in with his wife and employees is behind his parents' house with the same address. He still uses local models for photos in the studio and no longer uses walls as his trademark. However, he used the walls of his new house instead.

\section{Conclusion}

Based on the results of the analysis of the research that has been carried out, it can be concluded that the marketing strategy with endorsements carried out by Batik Kampus through Instagram and telegram has two types of endosers that apply, namely testimonials and celebrity attraction. Endorsement as a Batik Kampus marketing strategy in terms of Islamic Business Ethics as a whole on social media. The products that Batik Kampus promote are not exaggerating and in accordance with Islamic Sharia principles. Products that are traded include products that are polite and cover the body. The use of endorsement as a marketing strategy by Batik Kampus has had a significant positive impact as evidenced by the increased sales turnover and the increase in admins who help him in online business in the market place and proven by the assets owned by the young entrepreneur. Researchers also made observations by becoming a reseller of Batik Kampus, where the service is very fast, friendly and accepts dropshiping or packaging from Batik Kampus, which can make it easier for buyers to buy and resell Batik Kampus products to consumers directly.

Based on the results and findings of this study, the Batik Kampus Online shop can be used as an example of other businessmen in carrying out their business marketing strategies in accordance with Islamic Business Ethics and in order to cultivate Islamic endorsement in the Muslim community, researchers convey suggestions that there is a need for further detailed research on Endorsements that are in accordance with the theme of the researcher, companies that use endorsers services must provide 
intense and periodic sharia-based endorsement training so that it is in accordance with the guidance taught by Islamic Sharia and can help online business people develop their business. 


\section{References}

Adinugraha, H. H. (2018). Jurnal Ilmiah Ekonomi Islam , 4 ( 01 ), 2018 , 63-75 Al-Maslahah Al-Mursalah dalam Penentuan Hukum Islam. 4(01), 63-75.

Adinugraha, H. H., Novitasari, N., \& Ulama'i, A. H. A. (2019). The Role of Celebrity Endorser on Purchasing Intention of Halal Cosmetic [Peran Celebrity Endorser Terhadap Minat Beli Kosmetik Berlabel Halal]. Proceeding of Community Development, 2. https://doi.org/10.30874/comdev.2018.88

Ahmed, M., \& Cookson, R. (2016). WhatsApp and Instagram shift business models. Financial Times.

Alkhowaiter, W. (2016). The power of instagram in building small businesses. Social Media. Social Media: The Good, the Bad, and the Ugly Lecture Notes in Computer Science, 9844.

Anggraini, F. D., Kholipah, N., \& ... (2020). Pengaruh Penggunaan Internet Terhadap Bisnis Online Di Kediri Pada Masa Pandemi Covid-19. Seminar Nasional ..., September.

Appel, G., Grewal, L., Hadi, R., \& Stephen, A. T. (2020). The future of social media in marketing. Journal of the Academy of Marketing Science, 48(1). https://doi.org/10.1007/s11747-019-00695-1

Arfianti, U., \& Reswanda, R. (2020). Break Even Point Analysis As A Basic of Profit Planning In Handal Insan Sentosa Batik Business. Quantitative Economics and Management Studies, 1(3). https://doi.org/10.35877/454ri.qems1390

Arwani, A. (2019). Analisis Strategi Pemasaran Pengusaha Batik Kelurahan Banyurip Pekalongan Dengan Pendekatan Marketing Mix Berbasis Syariah. Li Falah: Jurnal Studi Ekonomi Dan Bisnis Islam, 4(1). https://doi.org/10.31332/lifalah.v4i1.1345

Aspers, P. (2009). Empirical Phenomenology: A Qualitative Research Approach (The Cologne Seminars). Indo-Pacific Journal of Phenomenology, 9(2). https://doi.org/10.1080/20797222.2009.11433992

Azizah, M. (2020). Penerapan Etika Bisnis Islam Dalam Transaksi Jual Beli Daring Di Toko Online Shopee. Fakultas Syariah, 10(1).

Barger, V. A., \& Labrecque, L. I. (2013). An integrated marketing communications perspective on social media metrics. International Journal of Integrated Marketing Communications, 5(1).

Belch, G. E., Belch, M. B., Kerr, G., Powell, I., \& Waller, D. (2020). Advertising: An Integrated Marketing Communication Perspective 4e. In Advertising and Promotion. An Integrated Marketing Communication Perspective.

Buldan, H., Hamid, E. S., Sriyana, J., \& Tohirin, A. (2021). The Role of Islamic Business Ethics and Market Condition on Organizational Performance. Journal of Asian Finance, Economics and Business, 8(1). https://doi.org/10.13106/jafeb.2021.vol8.no1.781

Campbell, C., \& Farrell, J. R. (2020). More than meets the eye: The functional components underlying influencer marketing. Business Horizons, 63(4). https://doi.org/10.1016/j.bushor.2020.03.003

Chakraborty, S., Giri, A., Biswas, S., \& Bag, M. (2020). Measuring the impact of celebrity endorsement on consumer purchase intention of beauty soap in Indian context. International Journal of Scientific and Technology Research, 9(2).

Chopra, A., Avhad, V., \& Jaju, and S. (2021). Influencer Marketing: An Exploratory Study to Identify Antecedents of Consumer Behavior of Millennial. Business Perspectives and Research, 9(1). https://doi.org/10.1177/2278533720923486

Crump, L. (2020). Conducting Field Research Effectively. American Behavioral Scientist, 64(2). https://doi.org/10.1177/0002764219859624

Devi S, L. R., \& Susantiningrum, S. (2017). Pengembangan Usaha Batik Melalui Mesin Pewarnaan Batik Di Desa Pilang Kecamatan Masaran Kabupaten Sragen. Jurnal Kewirausahaan Dan Bisnis, 20(11). https://doi.org/10.20961/jkb.v20i11.13988

Dyah Utami, A., \& Agus Triyono, R. (2011). Pemanfaatan Blackberry Sebagai Sarana Komunikasi Dan Penjualan Batik Online Dengan Sistem Dropship Di Batik Solo 85. Sentra Penelitian Engineering Dan 
Edukasi, 3(3).

Escursell, S., Llorach-Massana, P., \& Roncero, M. B. (2021). Sustainability in e-commerce packaging: A review. In Journal of Cleaner Production (Vol. 280). https://doi.org/10.1016/j.jclepro.2020.124314

Faradies, H. I. (2020). Strategi komunikasi city branding pemerintah kota Pekalongan dalam mempromosikan world's city of Batik. COMMICAST, $1(1)$. https://doi.org/10.12928/commicast.v1i1.2413

Fink, M., Koller, M., Gartner, J., Floh, A., \& Harms, R. (2020). Effective entrepreneurial marketing on Facebook - A longitudinal study. Journal of Business Research, 113. https://doi.org/10.1016/j.jbusres.2018.10.005

Ghoshal, D. M. (2019). Social Media as an Effective Tool to Promote Business- An Empirical Study. Global Journal of Management and Business Research: E Marketing, 19(1).

Good, V., Hughes, D. E., \& LaBrecque, A. C. (2021). Understanding and motivating salesperson resilience. Marketing Letters, 32(1). https://doi.org/10.1007/s11002-020-09552-6

Haerisma, A. S. (2018). Pengembangan Ekonomi Kreatif Bidang Fashion Melalui Bauran Pemasaran. AlAmwal: Jurnal Ekonomi Dan Perbankan Syari'ah, 10(1). https://doi.org/10.24235/amwal.v10i1.2831

Haikal, E. K., Freihat, S. M., Homsi, D., Joudeh, J. M. M., \& Hashem, T. N. (2020). The role of supply chain strategy and affiliate marketing in increasing the demand for ecommerce-Social media POV. International Journal of Supply Chain Management, 9(1).

Hakimi, B. Y., Abedniy, A., \& Zaeim, M. N. (2011). Investigate the impact of celebrity endorsement on brand image. European Journal of Scientific Research, 58(1).

Handayani, D. L. (2019). Etika Bisnis Islam: Sebuah Kajian Komparatif. Jurnal BAABU AL-ILMI: Ekonomi Dan Perbankan Syariah, 4(1). https://doi.org/10.29300/ba.v4i1.1852

Hapsari, W. (2016). Transformasi Hough Linear Untuk Analisis Dan Pengenalan Batik Motif Parang. Jurnal Informatika, 11(2). https://doi.org/10.21460/inf.2015.112.412

Hartati, A. (2019). Endorsement Sebagai Strategi Pemasaran Ditinjau Dari Etika Bisnis Islam (Studi Kasus di Hayu Olshop Metro). SKRIPSI, Institut Agama Islam Negeri (IAIN) Metro.

Hashim, N. A. B. (2017). Embracing the Instagram Waves -The New Business Episode to the Potential Entrepreneurs. Journal of Entrepreneurship and Business Innovation, 4(2). https://doi.org/10.5296/jebi.v4i2.12092

Herlina, E., \& Hakiki, N. (2020). ETIKA PEMASARAN BATIK PERSPEKTIF ISLAM Studi Kasus Cv. Hafiyan Desa Trusmi Kulon Kabupaten Cirebon. Jurnal Ekonomi Dan Manajemen, 15(2), 177-198.

Herman, J., Butow, E., \& Walker, C. (2018). Instagram for business. In 2020.

Iconsquare, \& HubSpot. (2016). How To Use Instagram For Business. HubSpot \& Iconsquare.

Islam, M. (2019). Starting up new business through instagram: Cases from South Korea. International Journal of Innovative Technology and Exploring Engineering, 8(12). https://doi.org/10.35940/ijitee.L3010.1081219

Ismaeel, M., \& Blaim, K. (2012). Toward applied Islamic business ethics: Responsible halal business. Journal of Management Development, 31(10). https://doi.org/10.1108/02621711211281889

Johan Grafström, L. J. \& P. W. (2018). The Impact of Influencer Marketing on Consumers ' Attitudes. Marketing Management, May.

K, E. M., \& Kozhukkal, M. M. (2020). A Study On The Role Of Instagram In Business Development Cycle Of Netpreneurs. Global Journal For Research Analysis. https://doi.org/10.36106/gjra/6907950

Keller, W. I. Y., Deleersnyder, B., \& Gedenk, K. (2019). Price Promotions and Popular Events. Journal of Marketing, 83(1). https://doi.org/10.1177/0022242918812055 
Kotler, P. (2017). Philip Kotler: some of my adventures in marketing. Journal of Historical Research in Marketing, 9(2). https://doi.org/10.1108/JHRM-11-2016-0027

Mofijur, M., Fattah, I. M. R., Alam, M. A., Islam, A. B. M. S., Ong, H. C., Rahman, S. M. A., Najafi, G., Ahmed, S. F., Uddin, M. A., \& Mahlia, T. M. I. (2021). Impact of COVID-19 on the social, economic, environmental and energy domains: Lessons learnt from a global pandemic. In Sustainable Production and Consumption (Vol. 26). https://doi.org/10.1016/j.spc.2020.10.016

Mukimin, A., Zen, N., Purwanto, A., Wicaksono, K. A., Vistanty, H., \& Alfauzi, A. S. (2017). Application of a full-scale electrocatalytic reactor as real batik printing wastewater treatment by indirect oxidation process. Journal of Environmental Chemical Engineering, 5(5). https://doi.org/10.1016/j.jece.2017.09.053

Nasih, M., Susanto, O. M., Fanshury, A. R., \& Hermawan, S. (2020). Influencer Dan Strategi Penjualan : Studi Netnografi Pada Pengguna Jasa Selebgram. BENEFIT: Jurnal Manajemen Dan Bisnis, 5(4).

Phelps, N. A., \& Wijaya, H. B. (2020). Growth and growth constraints in craft industry clusters: The batik industries of Central Java. Singapore Journal of Tropical Geography, 41(2). https://doi.org/10.1111/sjtg.12311

Purohit, S., Paul, J., \& Mishra, R. (2021). Rethinking the bottom of the pyramid: Towards a new marketing mix. Journal of Retailing and Consumer Services, 58. https://doi.org/10.1016/j.jretconser.2020.102275

Putritama, A. (2018). Penerapan Etika Bisnis Islam Dalam Industri. Jurnal Nominal, VII(1).

Ramdania, W. (2021). Etika Bisnis Islam Pada Perilaku Pemasaran Dan Kepuasan Konsumen. AsySyari'ah, 22(2). https://doi.org/10.15575/as.v22i2.8259

Rasyidi, M. A., \& Bariyah, T. (2020). Batik pattern recognition using convolutional neural network. Bulletin of Electrical Engineering and Informatics, 9(4). https://doi.org/10.11591/eei.v9i4.2385

Rosadi, A. P., Hidayat, A. R., \& Yunus, M. (2019). Tinjauan Etika Bisnis Islam terhadap Etika Endorser dalam Praktik Endorsement di Media Sosial Instagram ( Studi Kasus pada Nurul Fatimah ). Prosiding Hukum Ekonomi Syariah, 5(1).

Sampurno, W. M. (2016). Penerapan Etika Bisnis Islam dan Dampaknya Terhadap Kemajuan Bisnis Industri Rumah Tangga. Journal of Islamic Economics Lariba, 2(1).

Schimmelpfennig, C., \& Hunt, J. B. (2020). Fifty years of celebrity endorser research: Support for a comprehensive celebrity endorsement strategy framework. Psychology and Marketing, 37(3). https://doi.org/10.1002/mar.21315

Susanti, R. A. (2019). Strategi City Branding Pekalongan "World's City Of Batik." Gelar : Jurnal Seni Budaya, 16(1). https://doi.org/10.33153/glr.v16i1.2343

Tafesse, W., \& Wood, B. P. (2021). Followers' engagement with instagram influencers: The role of influencers' content and engagement strategy. Journal of Retailing and Consumer Services, 58. https://doi.org/10.1016/j.jretconser.2020.102303

Tran, L. T. T. (2021). Managing the effectiveness of e-commerce platforms in a pandemic. Journal of Retailing and Consumer Services, 58. https://doi.org/10.1016/j.jretconser.2020.102287

Venkata Subbiah, P., \& Sathish, A. S. (2020). Exploring the influences of celebrity endorsement on purchase intention and brand loyalty among rural youth. In Journal of Critical Reviews (Vol. 7, Issue 6). https://doi.org/10.31838/jcr.07.06.75

Waqas, M., Qalati, S. A., Shakir, H., \& Ashraf, S. F. (2020). Effects of Celebrity Endorsement , Promotional activities, Packaging of products, and Brand image, on Green Consumer buying behavior. Paradigms, 14(1).

Wenny Desty Febrian, \& Fitri, F. H. (2020). Pengaruh Penggunaan Jejaring Sosial Terhadap Produktivitas Pebisnis Onlineshop Dengan Motivasi Sebagai Variabel Moderasi. Jurnal Manajemen, 10(2). https://doi.org/10.30656/jm.v10i2.2521 
Widana, G. N. O., Wiryono, S. K., Purwanegara, M. S., \& Toha, M. (2014). Measuring Islamic business ethics within Indonesia Islamic banks. Global Journal Al-Thaqafah, 4(2). https://doi.org/10.7187/gjat622014.04.02

Widana, G. O., Wiryono, S. K., Purwanegara, M. S., \& Toha, M. (2015). Exploring the impact of islamic business ethics and relationship marketing orientation on business performance: The islamic banking experience. Asian Academy of Management Journal, 20(1).

Yu, S., \& Hu, Y. (2020). When luxury brands meet China: The effect of localized celebrity endorsements in social media marketing. Journal of Retailing and Consumer Services, 54. https://doi.org/10.1016/j.jretconser.2019.102010

Zhang, K., \& Hung, K. (2020). The effect of natural celebrity-brand association and para-social interaction in advertising endorsement for sustainable marketing. Sustainability (Switzerland), 12(15). https://doi.org/10.3390/su12156215

Zunaidi, A. (2015). Pemasaran Batik Madura Dalam Perspektif Manajemen Bisnis Syariah (Studi Kasus pada Batik "Jokotole" di Bangkalan Madura). Dinar, 1(2). 